and concern, and expresses its views on such issues in order to bring about action by parliaments and parliamentarians; contributes to the defence and promotion of human rights - an essential factor of parliamentary democracy and development; contributes to better knowledge of the working and development of representative institutions and to the strengthening of representative democracy.

Membership. The IPU had 155 members and nine associate members in Feb. 2011.

Headquarters: Chemin du Pommier 5, C.P. 330, 1218 Le

Grand Saconnex, Geneva 19, Switzerland.

Website: http://www.ipu.org

President: Theo-Ben Gurirab (Namibia).

Secretary-General: Anders B. Johnsson (Sweden).

\section{Interpol (International Criminal Police Organization)}

Organization. Interpol was founded in 1923, disbanded in 1938 and reconstituted in 1946. The International Criminal Police Organization-Interpol was founded to ensure and promote the widest possible mutual assistance between all criminal police authorities within the limits of the law existing in the different countries worldwide and the spirit of the Universal Declaration of Human Rights, and to establish and develop all institutions likely to contribute effectively to the prevention and suppression of ordinary law crimes.

Aims. Interpol provides a co-ordination centre (General Secretariat) for its 188 member countries. Its priority areas of activity concern criminal organizations, public safety and terrorism, drug-related crimes, financial crime and high-tech crime, trafficking in human beings and tracking fugitives from justice. Interpol centralizes records and information on international offenders; it operates a worldwide communication network.

Interpol's General Assembly is held annually. The General Assembly is the body of supreme authority in the organization. It is composed of delegates appointed by the members of the organization.

Interpol's Executive Committee, which meets four times a year, supervises the execution of the decisions of the General Assembly. The Executive Committee is composed of the president of the organization, the three vice-presidents and nine delegates.

Interpol's General Secretariat is the centre for co-ordinating the fight against international crime. Its activities, undertaken in response to requests from the police services and judicial authorities in its member countries, focus on crime prevention and law enforcement.

As of Feb. 2011 Interpol's Sub-Regional Bureaus were located in Abidjan, Buenos Aires, Harare, Nairobi, San Salvador and Yaoundé. Interpol's Liaison Office for Asia is located in Bangkok.

Headquarters: 200 Quai Charles de Gaulle, 69006 Lyon,

France.

Website: http://www.interpol.int

President: Khoo Boon Hui (Singapore).

\section{Islamic Development Bank}

The Agreement establishing the IDB (Banque islamique de développement) was adopted at the Second Islamic Finance
Ministers' Conference held in Jeddah, Saudi Arabia in Aug. 1974. The Bank, which is open to all member countries of the Organization of the Islamic Conference, commenced operations in 1975. Its main objective is to foster economic development and social progress of member countries and Muslim communities individually as well as jointly in accordance with the principles of the Sharia. It is active in the promotion of trade and the flow of investments among member countries, and maintains a Special Assistance Fund for member countries suffering natural calamities. The Fund is also used to finance health and educational projects aimed at improving the socio-economic conditions of Muslim communities in non-member countries. A US $\$ 1.5 b n$. IDB Infrastructure Fund was launched in 1998 to invest in projects such as power, telecommunications, transportation, energy, natural resources, petro-chemical and other infrastructurerelated sectors in member countries.

Members (56 as of Feb. 2011). Afghanistan, Albania, Algeria, Azerbaijan, Bahrain, Bangladesh, Benin, Brunei, Burkina Faso, Cameroon, Chad, Comoros, Côte d'Ivoire, Djibouti, Egypt, Gabon, Gambia, Guinea, Guinea-Bissau, Indonesia, Iran, Iraq, Jordan, Kazakhstan, Kuwait, Kyrgyzstan, Lebanon, Libya, Malaysia, Maldives, Mali, Mauritania, Morocco, Mozambique, Niger, Nigeria, Oman, Pakistan, Palestine, Qatar, Saudi Arabia, Senegal, Sierra Leone, Somalia, Sudan, Suriname, Syria, Tajikistan, Togo, Tunisia, Turkey, Turkmenistan, Uganda, United Arab Emirates, Uzbekistan, Yemen.

Official language: Arabic. Working languages: English, French. Headquarters: PO Box 5925, Jeddah 21432, Saudi Arabia.

Website: http://www.isdb.org

President: Ahmed Mohamed Ali (Saudi Arabia).

\section{Médecins Sans Frontières (MSF)}

Origin. Médecins Sans Frontières was founded in 1971 by a small group of doctors and journalists who believed that all people have a right to emergency relief.

Functions. MSF was one of the first non-governmental organizations to provide both urgently needed medical assistance and to publicly bear witness to the plight of the people it helps. Today MSF is an international medical humanitarian movement with branch offices in 19 countries. In 2008 MSF volunteer doctors, nurses, other medical professionals, logistical experts, water and sanitation engineers, and administrators departed on more than 4,600 missions and joined more than 23,900 locally hired staff to provide medical aid in over 65 countries. MSF was awarded the 1999 Nobel Peace Prize.

Headquarters: MSF International Office, Rue de Lausanne 78, CP 116, CH-1211 Geneva 21, Switzerland.

Website: http://www.msf.org

Secretary-General: Kris Torgeson (USA).

International Council President: Unni Karunakara (India).

\section{North Atlantic Treaty Organization (NATO)}

Origin. On 4 April 1949 the foreign ministers of Belgium, Canada, Denmark, France, Iceland, Italy, Luxembourg, the Netherlands, Norway, Portugal, the UK and the USA signed the North Atlantic Treaty, establishing the North Atlantic Alliance. In 1952 Greece 